\title{
0042. Burn injury stabilises extracellular atp and induces microvesicle production in skin
}

\author{
U Katbeh", M Takata, KP O'Dea \\ From ESICM LIVES 2014 \\ Barcelona, Spain. 27 September - 1 October 2014
}

\section{Introduction}

Microvesicles (MVs) are subcellular membrane-enclosed particles released from activated or dying cells with multiple functions, including induction of inflammation. A role for MVs has been indicated in sepsis- and traumarelated systemic inflammatory response syndrome (SIRS), but their production and function in severe burns injury is unknown. Extracellular ATP released from mechanically injured cells is an important stimulus for MV production [1], but this response is usually limited spatially as well as temporally by the rapid breakdown of extracellular ATP by ectoATPases. Due to the known sensitivity of ectoATPases to thermal inactivation [2], we hypothesised that ATP released during thermal injury would be stable and capable of inducing MVs from viable responder cells within the burn tissue microenvironment.

\section{Objectives}

To investigate the release of ATP from thermallyinjured cells and its potential role in inducing $\mathrm{MV}$ release from burn-injured tissue.

\section{Methods}

In vitro cultured human keratinocytes were injured thermally by incubation at $95^{\circ} \mathrm{C}$ for up to 60 seconds, or mechanically by one freeze-thaw cycle. ATP release was quantified using a fluorimetric assay. An ex vivo mouse skin explant model was developed in which skin pieces were exposed to steam for 15 or 60 secs, or to ATP $(6 \mathrm{mM})$ sub-dermally, and then incubated in medium for 2 hours at $37^{\circ} \mathrm{C}$. Released MVs were analysed by flow cytometry. Skin oedema was assessed by weight gain during the incubation period.

Imperial College London, Section of Anaesthetics, Pain Medicine and Intensive Care, London, UK

(c) 2014 Katbeh et al; licensee Springer. This is an Open Access article distributed under the terms of the Creative Commons Attribution License (http://creativecommons.org/licenses/by/2.0), which permits unrestricted use, distribution, and reproduction in any medium, provided the original work is properly cited.

\section{Results}

ATP was released by thermal injury to keratinocytes and remained stable for up to 3 hours at $37^{\circ} \mathrm{C}$ (Fig. 1). In contrast, ATP released by freeze-thawing decayed rapidly. Incubation of skin explants with ATP produced
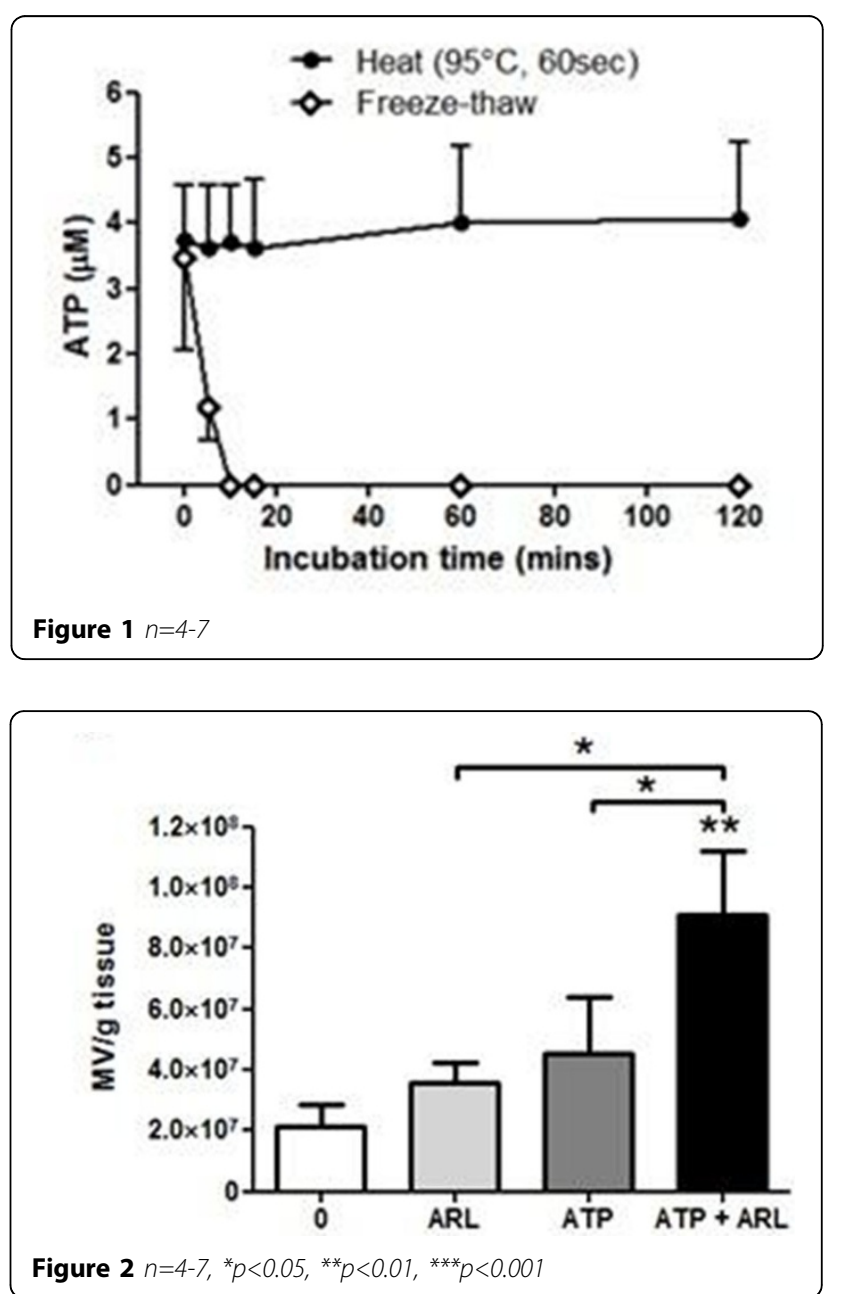

Figure $2 n=4-7,{ }^{*} p<0.05,{ }^{* *} p<0.01,{ }^{* * *} p<0.001$ 

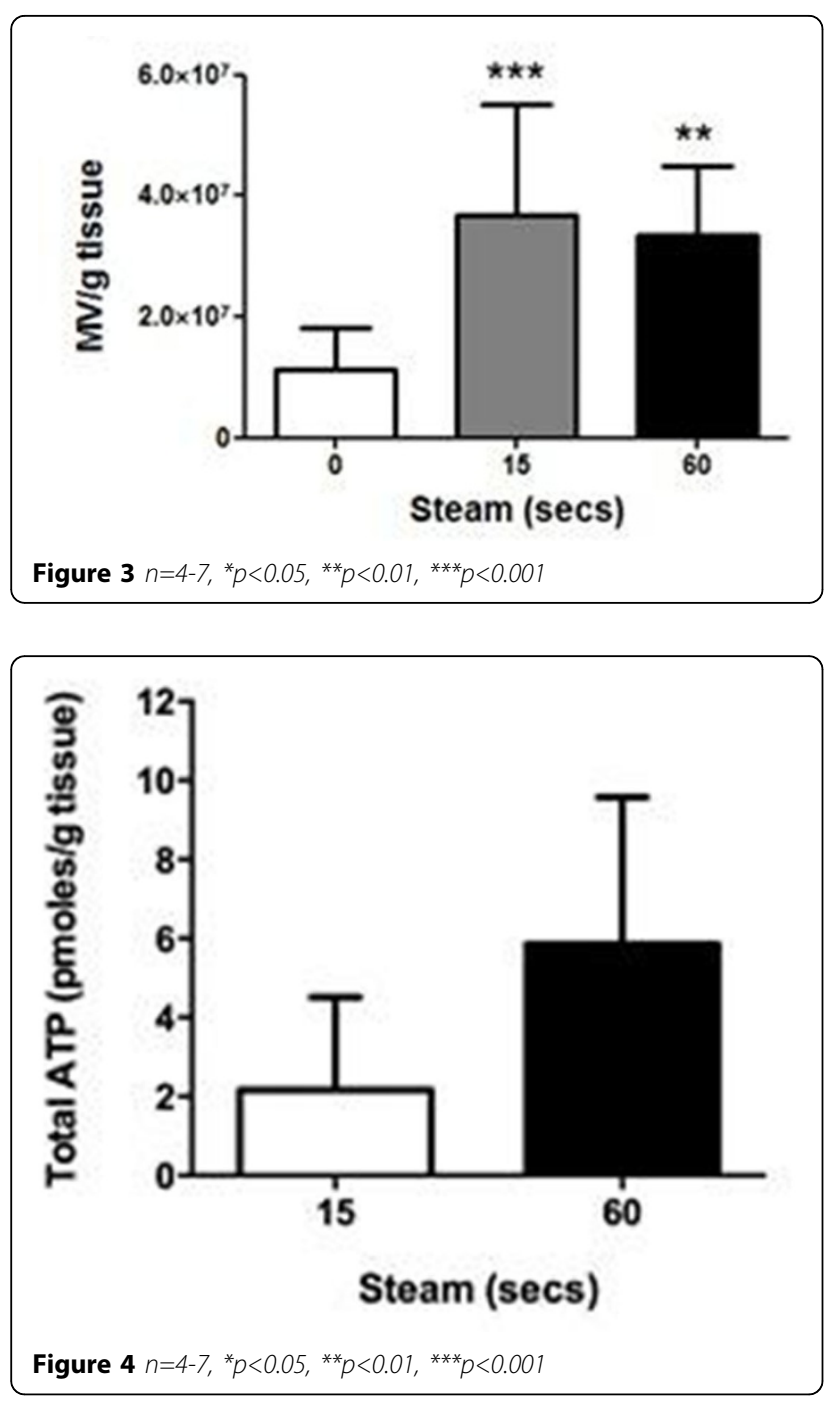

significant MV release (Fig. 2), but this effect required the presence of an ectoATPase inhibitor (ARL 67156) presumably due to prevention of the normal extracellular ATP degradation process. Exposure of skin to steam for 15 or 60 secs produced significant increases in MV release into the medium (Fig. 3), while ATP was detectable in medium from steam-exposed but not untreated skin (Fig. 4). Skin weight significantly increased with 15 $(17.8 \pm 4.3 \%, \mathrm{p}<0.05, \mathrm{n}=6)$ and $60 \operatorname{secs}(40.0 \pm 18.2 \%$, $\mathrm{p}<0.001, \mathrm{n}=6)$ steam exposure confirming that both treatments produced a burn injury.

\section{Conclusions}

These results demonstrate that burn injury can elicit MV production and that ATP release from injured cells could play a central role in this process. The stabilisation of extracellular ATP by burn injury would produce a unique pathophysiological environment for MV production, which, if released systemically, would play an important and more significant role in promoting systemic inflammation following severe burn injury as compared to other SIRS aetiologies.

\section{Grant acknowledgment}

Funded by the Chelsea and Westminster Health Charity.

Published: 26 September 2014

\section{References}

1. Bianco F, et al: J Immunol 2005, 174:7268-7277.

2. Despa F, et al: Burns 2005, 31:568-577.

doi:10.1186/2197-425X-2-S1-011

Cite this article as: Katbeh et al:: 0042. Burn injury stabilises extracellular atp and induces microvesicle production in skin. Intensive Care Medicine Experimental 2014 2(Suppl 1):011.

\section{Submit your manuscript to a SpringerOpen ${ }^{\circ}$ journal and benefit from:}

- Convenient online submission

- Rigorous peer review

- Immediate publication on acceptance

- Open access: articles freely available online

- High visibility within the field

- Retaining the copyright to your article

Submit your next manuscript at $>$ springeropen.com 